\title{
"Technical analysis testing in forecasting Socially Responsible Investment Index in Indonesia Stock Exchange"
}

\begin{tabular}{|c|c|}
\hline AUTHORS & $\begin{array}{l}\text { Dolly Parlagutan Pulungan (D https://orcid.org/0000-0003-4728-9529 } \\
\text { Sugeng Wahyudi (D http://orcid.org/0000-0003-2889-7123 } \\
\text { Suharnomo Suharnomo (D https://orcid.org/0000-0002-6624-4409 } \\
\text { Harjum Muharam (D https://orcid.org/0000-0002-4627-9997 }\end{array}$ \\
\hline ARTICLE INFO & $\begin{array}{l}\text { Dolly Parlagutan Pulungan, Sugeng Wahyudi, Suharnomo Suharnomo and } \\
\text { Harjum Muharam (2018). Technical analysis testing in forecasting Socially } \\
\text { Responsible Investment Index in Indonesia Stock Exchange. Investment } \\
\text { Management and Financial Innovations, 15(4), 135-143. } \\
\text { doi:10.21511/imfi.15(4).2018.11 }\end{array}$ \\
\hline DOI & http://dx.doi.org/10.21511/imfi.15(4).2018.11 \\
\hline RELEASED ON & Monday, 12 November 2018 \\
\hline RECEIVED ON & Tuesday, 07 August 2018 \\
\hline ACCEPTED ON & Wednesday, 07 November 2018 \\
\hline LICENSE & $\begin{array}{l}(c) \mathbf{E Y} \\
\text { This work is licensed under a Creative Commons Attribution } 4.0 \text { International } \\
\text { License }\end{array}$ \\
\hline JOURNAL & "Investment Management and Financial Innovations" \\
\hline ISSN PRINT & $1810-4967$ \\
\hline ISSN ONLINE & $1812-9358$ \\
\hline PUBLISHER & LLC "Consulting Publishing Company "Business Perspectives" \\
\hline FOUNDER & LLC "Consulting Publishing Company "Business Perspectives" \\
\hline
\end{tabular}

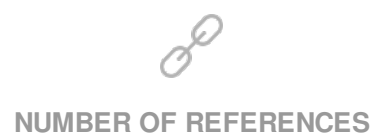

35

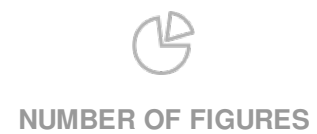

0
琵

NUMBER OF TABLES

4

(C) The author(s) 2022. This publication is an open access article. 


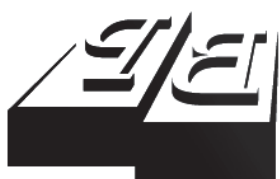

BUSINESS PERSPECTIVES

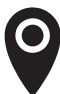

LLC “CPC "Business Perspectives” Hryhorii Skovoroda lane, 10, Sumy, 40022, Ukraine

www.businessperspectives.org

Received on: $7^{\text {th }}$ of August, 2018 Accepted on: $7^{\text {th }}$ of November, 2018

(C) Dolly Parlagutan Pulungan, Sugeng Wahyudi, Suharnomo Suharnomo, Harjum Muharam, 2018

Dolly Parlagutan Pulungan, Doctoral Program in Economics (Ph.D. Student), Faculty of Economics and Business, Universitas Diponegoro, Central Java, Indonesia.

Sugeng Wahyudi, Professor, Faculty of Economics and Business, Universitas Diponegoro, Central Java, Indonesia.

Suharnomo Suharnomo, Ph.D., Dean, Faculty of Economics and Business, Universitas Diponegoro, Central Java, Indonesia.

Harjum Muharam, Ph.D., Head of Management Department, Faculty of Economics and Business, Universitas Diponegoro, Central Java, Indonesia.

\section{(c) (i)}

This is an Open Access article, distributed under the terms of the Creative Commons Attribution 4.0 International license, which permits unrestricted re-use, distribution, and reproduction in any medium, provided the original work is properly cited.
Dolly Parlagutan Pulungan (Indonesia), Sugeng Wahyudi (Indonesia),

Suharnomo Suharnomo (Indonesia), Harjum Muharam (Indonesia)

\begin{abstract}
This study aims to examine whether the Autoregressive Integrated Moving Average (ARIMA) model is appropriate to be applied in the Indonesia Stock Exchange, especially for the socially resposible investment stocks. For the ARIMA model combines the autoregressive and moving average method, so it is viewed as a useful tool to predict the stock prices. Those methods are frequently used methods to forecast the stock prices. The data used in this study were daily SRI-KEHATI Index during the period of June 8, 2009 to July 17, 2017. The results showed that the daily SRI-KEHATI Index data were not stationary data, thus this data needed to be transformed. The transformation was done by using the first seasonal differencing transformation process. After being transformed, those data became stationary. Furthermore, this study found that ARIMA $(3,1,1)$ was a model, which might be appropriate and fit with the data condition. This method was also relevant to be applied in the Indonesia Stock Exchange in order to forecast the stock prices.
\end{abstract}

Keywords

Autoregressive Integrated Moving Average (ARIMA), SRI-KEHATI Index, Indonesia Stock Exchange (IDX), technical analysis, estimation

JEL Classification G10, G17

\section{INTRODUCTION}

A capital market is a place for corporations to find funds for their activities. Meanwhile, for those who have excess funds and are interested in investing, the capital market can be an alternative investment. The capital market is expected to be able to play an intermediary role so that it also contributes to the national economy. The presence of capital market institutions in Indonesia has added alternatives for investors to invest their funds. Many types of securities are sold in the market, one of them which is traded is stock. During the period 2010-2017, the Indonesian capital market (Indonesia Stock Exchange or IDX) has grown significantly in terms of transaction value, as shown in Table 1.

During the period 2010-2017, the stock transaction value in IDX has grown up to $53.8 \%$. This fact shows that stocks became such a preferred investment instrument in Indonesia. However, stocks are high-risk investment instruments (Hartono, 2015), which need to be carefully analyzed. Stocks are categorized into different class assets with fixed income instruments (Robiyanto, Wahyudi, \& Pangestuti, 2017a, 2017b). Stocks can be influenced by various factors, both comf pany's internal and external factors, such as economic conditions and even technical factors (Artha, Achsani, \& Sasongko, 2014; Setiawan \& Fathony, 2015; Triyono \& Robiyanto, 2017). Therefore, investors and 
Table 1. Stock transaction value in the Indonesia Stock Exchange during the period 2010-2017

Source: The Indonesia Financial Service Authority.

\begin{tabular}{c|cc}
\hline Period & Stock transaction value (in billion rupiahs) \\
\hline 2010 & $1,176,237.42$ & $1,223,440.51$ \\
2011 & $1,116,113.25$ & $1,522,122.36$ \\
2012 & $1,453,392.36$ \\
2013 & $1,406,367.63$ \\
2014 & & $1,844,590.00$ \\
2015 & $1,809,590.00$ \\
\hline 2016 & & \\
\hline 217 & & \\
\hline
\end{tabular}

future stock investors must first actively analyze them before investing in stocks (Ernayani, Oktiviana, \& Robiyanto, 2017; Khafid \& Mukhibad, 2016; Robiyanto, 2017; Wijaya, 2017).

Generally, stock analysis is divided into two, namely fundamental and technical analysis (Sharpe, Gordon, \& Bailey, 1995). Ang (1997) stated that fundamental analysis is basically a historical analysis of financial performance and this process is often referred to as corporate analysis, while technical analysis is a study conducted to understand various forces that influence the stock market and the implications on the stock prices. To be more specific, Archelis (2000) stated that technical analysis is an attempt to estimate stock prices (market conditions) by observing changes in stock prices (market conditions) in the past. Nevertheless, technical analysis can be done not only on the stocks, but it can also be done to forecast the price of a commodity or foreign currency (Badev \& Chen, 2014; Fernández-Rodríguez, Gonzalez-Martel, \& Sosvilla-Rivero, 1999; Martin, 2001).

In relation to the implementation of analysis in the stock market, Parisi and Vasquez (2000) suggested that technical analysis focuses on the ways to estimate a stock price. The underlying theory used is that the technical analysis is based on the fact that information enters slowly into stock prices, allowing investors to gain excessive returns by observing stock price movements. The technical analysis can be carried out by using forecasting methods such as moving average (MA), exponential moving average (EMA) and trend analysis (Parisi \& Vasquez, 2000), yet these three forecasting methods can be combined into one forecasting technique called ARIMA (Autoregressive Integrated Moving Average).

In relation to the ARIMA forecasting techniques, Sugiarto and Harijono (2000) stated that ARIMA is actually a technique for finding the most suitable pattern from a group of data (curve fitting), thus ARIMA makes full use of the past and present data to perform accurate short-term forecasting. One example on the use of the ARIMA model is to forecast the stock prices in the capital market conducted by the brokers based on the patterns of stock price changes in the past (Sugiarto \& Harijono, 2000). Although ARIMA is a combination of the three forecasting method techniques (EMA, MA and trend analysis), it turns out that this method is rarely used and studied in researches on technical analysis on the Indonesia Stock Exchange. The previous researches on technical analysis that have been conducted are such as those by Artha et al. (2014), Prabhata (2012), Setiawan and Fathony (2015), Tobing (2015), Yudono (2010). Those studies have been done to examine whether some individual stocks can be analyzed by using technical analysis. Another study was also done by Mukti (2018) who conducted a study to examine whether a technical analysis indicator named Ichimoku No Kinko Hyo was approriate to be used in IDX. Mukti (2018) used Jakarta Islamic Index (JII) in his study. Waworuntu and Suryanto (2010) and Ardani, Murhadi, and Marciano (2012) examined the potency of technical analysis in LQ-45 stock listed in the Indonesia Stock Exchange. They found that technical analysis was a useful tool to trade in the Indonesia Stock Exchange.

Studies in the Indonesia Stock Exchange tend to use individual stocks, LQ-45 stocks and Islamic stocks in their analysis. None has been done to examine whether the technical analysis is applicable for the 
socially responsible investment stocks, although a concern on socially responsible investment is growing nowadays as the Sustainable Development Goals (SDG) have been innitiated. Based on this description, in this research, there would be conducted a study of the technical analysis in the Indonesian capital market, which is the Indonesia Stock Exchange, by using ARIMA forecasting method. The ARIMA method was used in this study, because it could be used for all data types and it would work well if the time series data used are dependent or statistically related to each other (Sugiarto \& Harijono, 2000). This is in accordance with an assumption on technical analysis, which states that history will repeat itself. This research would specifically study the Socially Responsible Investment Index (SRI-KEHATI) on the Indonesia Stock Exchange, because the shares forming the SRI-KEHATI Index are environmentally aware, socially aware, and have good corporate governance (Robiyanto, 2018; Zulkafli, Ahmad, \& M., 2017) and if they are combined, they have a market capitalization of more than $50 \%$ on the Indonesia Stock Exchange.

\section{LITERATURE REVIEW}

Technical approach is a stock analysis technique, which is conducted by using historical data regarding the development of stock prices and stock trading volumes in a graph/chart pattern, and then used as a decision-making model. Supply and demand will be used to forecast the future price levels and movements. Technical analysis is the most widely used analytical technique by investors, even a research by Fernández-Rodríguez et al. (1999) stated that more than $90 \%$ of investors put more emphases on the use of technical analysis rather than the fundamental analysis in buying or selling shares.

The technical assumptions include (Archelis, 2000):

\section{MARKET ACTION DISCOUNTS EVERYTHING}

Market reaction will occur according to the market conditions, whereas if the offer is more than the bid, the price will move down, and vice versa, whereas if the offer is less than the bid, the price will move up.

\section{PRICE MOVE IN TRENDS}

The stock prices will move according to the market conditions, as previously explained. If a stock price has moved up or down, then the stock price will follow the previous pattern until the latest news or issue exist.

\section{HISTORY REPEATS ITSELF}

The stock price movements that have occurred will always be attached to the investors' mind and tend to be a reference for an investor to make investment decisions.

Parisi and Vasquez (2000), Fernández-Rodríguez $(1999,2000,2001)$ stated that in the technical analysis, there are methods, which become the basic trading rules. They include indicators such as moving average, exponential moving average and trend lines.

The moving average (MA) method is a simple technical analysis method. It is performed by looking for the moving average of daily stock prices over several periods, and the number of periods that are often used for this calculation are 5, 20 and 100 periods. Another moving average method is the exponential moving average (EMA) that has almost the same principles as the MA, but the EMA also considers the weight of the previous period. Meanwhile, the trend line method is a method to forecast stock prices by using a simple regression technique with time as an independent variable.

The three methods can be combined into forecasting techniques called ARIMA (FernándezRodríguez et al., 1999; Fernández-Rodríguez, Sosvilla-Rivero, \& Andrada-Félix, 2000).

\section{ARIMA (AUTOREGRESSIVE INTEGRATED MOVING AVERAGE)}

ARIMA (Autoregressive Integrated Moving Average) model is an intensive model developed by George Box and Gwilyn Jenkins. Therefore, their names are often synonymous with the ARIMA process applied for the analysis and 
forecasting the time series data. ARIMA is actually a technique to find the most suitable pattern from a group of data (curve fitting), thus ARIMA makes full use of the past and present data to perform accurate short-term forecasting. An example on the use of the ARIMA model is forecasting stock prices in the capital market conducted by the brokers based on the patterns of stock price changes in the past (Makridakis, Wheelwright, \& Hyndman, 1998; Sugiarto \& Harijono, 2000). ARIMA has also been used in several empirical studies on the Indonesia Stock Exchange, for example, a research by Qizam (2001) which used ARIMA to analyze the company's profit behavior in the Jakarta Stock Exchange. In Qizam (2001), it was concluded that the ARIMA method was still relevant in describing the earnings behavior.

\subsection{Notation in the ARIMA model}

In general, the ARIMA (Box-Jenkins) model is formulated with the following notation (Makridakis et al., 1998; Sugiarto \& Harijono, 2000):

$\operatorname{ARIMA}(p, d, q)$.

In this case, $p$ shows the order/degree of autoregressive (AR), $d$ shows the order/degree of differencing (differentiation) and $q$ shows the order/degree of moving average (MA), autoregressive model (AR).

Autoregressive model is a model that describes that the dependent variable is influenced by the dependent variable itself in the previous periods and times (Fildes \& Makridakis, 1995; Sugiarto \& Harijono, 2000). In general, the autoregressive (AR) model has the following form:

$$
Y_{1}=\Theta_{0}+\Theta_{1} Y_{t-1}+\ldots+\Theta_{p} Y_{t-p}+\varepsilon_{t},
$$

where $Y_{t}$ is the value of the dependent variable at time $t$ (an independent variable), which in this case is a lag (time difference) of the dependent variable in the previous period to $p$ of the previous period, $\Theta_{0}$ is an intercept, $\Theta_{1}, \Theta_{2}, \Theta_{p, t}$ are the coefficients or parameters of the autoregressive model, $\varepsilon_{t}$ is the residual at time $t$.

The order of the AR model (which is given as a $p$ notation) is determined by the number of depen- dent variable period included in the model. For example:

$Y_{t}=\Theta_{0}+\Theta_{1} Y_{t-1}$ is the first order of AR model with ARIMA notation $(1,0,0)$,

$Y_{t}=\Theta_{0}+\Theta_{1} Y_{t-1}+\Theta_{2} Y_{t-2}$ is the second order of AR model with ARIMA notation $(2,0,0)$.

The above model is called the autoregressive model (self-regression), because the model is similar to the regression equation in general. It is just that the independent variable is not another variable, which is different from the dependent variable but the previous value (lag) of the dependent variable $Y_{t}$ itself.

\subsection{Moving average (MA) model}

In general, the moving average model has the following form:

$Y_{t}=w_{0}+\varepsilon_{t}-w_{1} \varepsilon_{t-1}-w_{2} \varepsilon_{t-2}-\ldots-w_{q} \varepsilon_{t-q}$,

where $Y_{t}$ is the value of the dependent variable at time $t, \varepsilon_{t-1}, \varepsilon_{t-2}, \ldots, \varepsilon_{t-q}$ show the value of previous residual (lag), $w_{1}, w_{2}, \ldots, w_{q}$ are the coefficients of the moving average model that shows weights, $\varepsilon_{t}$ is the residual.

The difference between the moving average model and the autoregressive model lies in the type of the independent variable. If the independent variable in the autoregressive model is the previous value (lag) of the dependent variable $Y_{t}$ itself, then the moving average model as the independent variable is the residual value in the previous period. Although the coefficient $w$ has a negative sign, it can be positive or negative.

The order of the MA value (which is given as a $q$ notation) is determined by the number of the independent variable period included in the model. For example:

$Y_{t}=w_{0}+\varepsilon_{t}-w_{1} \varepsilon_{t-1}$ is the first order of MA model with ARIMA notation $(0,0,1)$,

$Y_{t}=w_{0}+\varepsilon_{t}-w_{1} \varepsilon_{t-1}-w_{2} \varepsilon_{t-2}$ is the second order of MA model with ARIMA notation $(0,0,2)$. 


\subsection{ARIMA model}

AR and MA models can be combined to produce the ARIMA model (Autoregressive Integrated Moving Average) with the following general form:

$Y_{T}=B_{1} Y_{t-1}+B_{2} Y_{t-2}+\ldots B_{2} Y_{t-P}+e_{T}$

$-W_{1} e_{t-1}-W_{2} e_{t-2} \ldots+W_{q} e_{t-q}+e_{t}$,

where $B$ - regression coefficient, $Y_{t}$ - dependent variable at time $t, Y_{t-1} \ldots Y_{t-p}$ - lag variable, $e_{t}$ residual term, $W_{1} \ldots W_{q}$ - weight, $e_{t-1} \ldots e_{t-q}$ - previous value or residual.

The ARIMA model uses both the previous value (lag) of the dependent variable and the residual value of the previous period. With this combination, it is expected that the ARIMA model can accommodate the data patterns that cannot be identified individually by the MA model or AR model.

The order of the ARIMA model is determined by the number of independent variable periods, both from the previous value (lag) of the dependent variable and the residual value of the previous period. For example:

$Y_{t}=\Theta_{0}+\Theta_{1} Y_{t-1}-w_{1} \varepsilon_{t-1}+\varepsilon_{t}$ is the ARIMA model $(1,0,1)$,

$Y_{t}=\Theta_{0}+\Theta_{1} Y_{t-1}+\Theta_{2} Y_{t-2}-w_{1} \varepsilon_{t-1}+\varepsilon_{t}$ is the ARIMA model $(2,0,1)$,

$Y_{t}=\Theta_{0}+\Theta_{1} Y_{t-1}-w_{1} \varepsilon_{t-1}-w_{2} \varepsilon_{t-2}+\varepsilon_{t} \quad$ is the ARIMA model $(1,0,2)$,

$Y_{t}=\Theta_{0}+\Theta_{1} Y_{t-1}+\Theta_{2} Y_{t-2}-w_{1} \varepsilon_{t-1}-w_{2} \varepsilon_{t-2}+\varepsilon_{t}$ is the ARIMA model $(2,0,2)$.

\section{HYPOTHESIS DEVELOPMENT}

A good stock price forecast is a forecast, which is able to accurately forecast the stock prices in the future or in a certain period. Therefore, the results of a stock price forecast, which is done by using a good forecasting technique, is the forecasting, which is not different from the actual stock price. It also applies to the ARIMA method, where it will be considered relevant if it has a low error rate of prediction and can fit to the data conditions (Makridakis et al., 1998).

ARIMA, as a forecasting tool, is expected to be relevant to be applied on the Indonesia Stock Exchange. This is based on the fact that ARIMA uses the lag variable (previous stock price) in stock forecasting. The findings by Robiyanto (2000, 2015), Robiyanto and Puryandani (2015) showed that the past stock prices had a significant influence on the future stock prices. Besides, ARIMA also involves the moving average, which is one of the most commonly used technical analysis indicators by the investors (Fernández-Rodríguez et al., 2000).

Based on the description above, the hypothesis proposed is as follows:

H1: Past stock prices influence the future stock prices.

\section{RESEARCH METHOD}

\subsection{Data}

The data used in this study were the daily closure of the SRI-KEHATI Index data from the period of June 8, 2009 to July 17, 2017 (the number of trading days was 1,976 days). This data were obtained from Bloomberg.

\subsection{Analysis technique}

Before the ARIMA analysis was conducted, it must first be tested whether the data were stationary or not. The stationary data test was carried out by using the Augmented Dickey-Fuller test. To determine the model used, partial autocorrelation test with Q-stat was performed.

\subsection{Hypothesis testing}

The hypothesis testing was done by using LjungBox Q Statistics for the residuals of the model. Ljung-Box Q Statistics is an improvement from Box-Pierce Q Statistics and is more adequate to use on the data with very large periods (Greene, 2003). The Ljung-Box Q Statistics value is the same as the Chi-square value, so the comparison is the table of Chi-square value. If the Ljung-Box Q Statistics value is greater than the table of Chi-square value 
or has a probability value to be smaller than $5 \%$, then it is concluded that the past residuals influence the residuals in the next period. In this study, H1 stating that the past stock prices influence the future stock prices would be accepted if the LjungBox Q Statistics value is greater than the table of Chi-square value.

\section{FINDINGS AND DISCUSSION}

The data were analyzed by using the ARIMA method. Before calculating by using the ARIMA method, a series of tests such as data stationary tests, and tests to determine the values of $p, d$ and $q$ were carried out.

\subsection{Result of stationarity test}

The data stationary test results by using Augmented Dickey-Fuller test can be seen in Table 2 .

Table 2. Result of Augmented Dickey-Fuller (ADF) test

Source: Bloomberg, processed

\begin{tabular}{l|c:c}
\hline \multicolumn{1}{c}{ Variable } & ADF test statistic & Prob. \\
\hline Level & -1.164017 & 0.6919 \\
\hdashline First difference & -29.11102 & 0.0000 \\
\hdashline Second difference & -23.43828 & 0.0000 \\
\hline
\end{tabular}

Based on the Augmented Dickey-Fuller test, it can be concluded that the SRI-KEHATI data used were not stationary in the form level, but were stationary with the first difference and second difference. Therefore, this study used the data with the first difference.

\subsection{Result of partial autocorrelation (PAC) test}

The partial autocorrelation (PAC) test was performed to determine the $p$-value in the ARIMA equation. Table 2 shows that the first significant lag is lag 3. This indicates that the process is the AR (3) process. Based on this, the autoregression coefficient $p$ then was set at 3. A seasonal differencing had also been carried out in the previous section. The value of $d$ was determined as 1 , this was because the initial data that were not stationary previously could be transformed into the stationary one by using a seasonal differencing of 1 . Unlike the determination of $p$ and $d$ values, the determination of the MA $(q)$ coefficient was not done in a special way. Greene (2003) stated that the small MA coefficient tends to be more effective. Thus, the MA value, which is often used, is 1. Based on this, this study used the MA $(q)$ value of 1 . Therefore, the ARIMA model in this study used a $p$ value of 3 , a $d$ value of 1 and a $q$ value of 1 , which could be written into ARIMA $(3,1,1)$.

Table 3. Result of PAC test

Source: Bloomberg, processed.

\begin{tabular}{|c|c|c|c|c|c|c|}
\hline $\begin{array}{l}\frac{5}{0} \\
\frac{0}{0} \\
\frac{\pi}{0} \\
\frac{2}{2} \\
\frac{0}{2} \\
\frac{0}{2}\end{array}$ & & ָָ & $\underset{\leftarrow}{\longleftarrow}$ & $\underset{\Sigma}{\longleftarrow}$ & $\frac{\dot{\pi}}{\frac{\pi}{0}}$ & $\frac{\dot{0}}{0}$ \\
\hline 11 & II & 1 & 0.040 & 0.040 & 3.1005 & 0.078 \\
\hline 11 & 11 & 2 & -0.037 & -0.039 & 5.8716 & 0.053 \\
\hline$* 11$ & $* \mid 1$ & 3 & -0.118 & -0.115 & 33.341 & 0.000 \\
\hline 11 & 11 & 4 & -0.059 & -0.052 & 40.267 & 0.000 \\
\hline 11 & 11 & 5 & -0.010 & -0.015 & 40.455 & 0.000 \\
\hline 11 & $* \mid 1$ & 6 & -0.061 & -0.079 & 47.895 & 0.000 \\
\hline 11 & II & 7 & 0.034 & 0.025 & 50.211 & 0.000 \\
\hline 11 & 11 & 8 & 0.010 & -0.003 & 50.410 & 0.000 \\
\hline|| & 11 & 9 & 0.018 & 0.002 & 51.046 & 0.000 \\
\hline 11 & 11 & 10 & 0.045 & 0.045 & 55.003 & 0.000 \\
\hline 11 & 11 & 11 & -0.027 & -0.027 & 56.481 & 0.000 \\
\hline 11 & I I & 12 & 0.032 & 0.037 & 58.519 & 0.000 \\
\hline 11 & 11 & 13 & -0.028 & -0.017 & 60.101 & 0.000 \\
\hline 11 & 11 & 14 & -0.036 & -0.035 & 62.729 & 0.000 \\
\hline 11 & I I & 15 & -0.027 & -0.019 & 64.130 & 0.000 \\
\hline 11 & 11 & 16 & -0.007 & -0.006 & 64.227 & 0.000 \\
\hline 11 & 11 & 17 & -0.019 & -0.038 & 64.937 & 0.000 \\
\hline I I & II & 18 & 0.025 & 0.023 & 66.173 & 0.000 \\
\hline 11 & 11 & 19 & 0.014 & -0.000 & 66.576 & 0.000 \\
\hline 11 & 11 & 20 & 0.000 & -0.012 & 66.576 & 0.000 \\
\hline 11 & I I & 21 & -0.005 & -0.000 & 66.632 & 0.000 \\
\hline 11 & 11 & 22 & -0.026 & -0.026 & 67.961 & 0.000 \\
\hline 11 & II & 23 & 0.002 & 0.004 & 67.967 & 0.000 \\
\hline 11 & I I & 24 & 0.002 & 0.005 & 67.978 & 0.000 \\
\hline 11 & 11 & 25 & 0.037 & 0.032 & 70.719 & 0.000 \\
\hline 11 & 11 & 26 & 0.044 & 0.042 & 74.602 & 0.000 \\
\hline II & I I & 27 & 0.013 & 0.016 & 74.923 & 0.000 \\
\hline 11 & 11 & 28 & 0.032 & 0.036 & 76.956 & 0.000 \\
\hline 11 & 11 & 29 & -0.010 & 0.007 & 77.150 & 0.000 \\
\hline 11 & I I & 30 & 0.041 & 0.052 & 80.564 & 0.000 \\
\hline 11 & 11 & 31 & -0.032 & -0.023 & 82.624 & 0.000 \\
\hline 11 & 11 & 32 & -0.048 & -0.034 & 87.229 & 0.000 \\
\hline I I & I I & 33 & -0.064 & -0.057 & 95.547 & 0.000 \\
\hline 11 & 11 & 34 & -0.024 & -0.024 & 96.664 & 0.000 \\
\hline 11 & 11 & 35 & 0.044 & 0.022 & 100.57 & 0.000 \\
\hline || & | | & 36 & 0.002 & -0.020 & 100.58 & 0.000 \\
\hline
\end{tabular}




\subsection{Result of ARIMA $(3,1,1)$}

The stationary test data shows that the SRIKEHATI Index data were not stationary and required a transformation. By using a seasonal differencing for 1 periodicity, the stationary data were obtained, so that it was feasible to do the ARIMA analysis. Based on the results of the diagnosis, it was determined that the ARIMA analysis to be conducted was ARIMA $(3,1,1)$. The results of the analysis can be seen in Table 4 .

Table 4. Result of ARIMA $(3,1,1)$

\begin{tabular}{l|c:c} 
& \multicolumn{2}{c}{ Source: Bloomberg, processed. } \\
\hline \multicolumn{1}{c|}{ Variable } & Coefficient & t \\
\hline Constant & 0.123 & $2.227^{*}$ \\
\hline AR(1) & 0.561 & $4.571^{* *}$ \\
\hline AR(2) & -0.056 & $-2.130^{*}$ \\
\hdashline AR(3) & -0.092 & $-3.428^{* *}$ \\
\hdashline MA(1) & 0.533 & $4.359^{* *}$ \\
\hline Ljung-Box & & \\
Q(18):25.970* & & \\
\hline
\end{tabular}

Notes: ${ }^{*}$ Significant at $5 \%$ significance level, ${ }^{* *}$ significant at $1 \%$ significance level.

The autoregressive coefficient of the ARIMA $(3,1,1)$ model for each AR (1), AR (2), and AR (3) are 0.561, $-0.056,-0.092$ with each value of $t$ as much as 4.571 , $-2.130,-3.428$. The coefficient value of $t$ of the autoregressive AR (1) and AR (3) are significant at $1 \%$ significance level, while the coefficient value of $t$ of the autoregressive AR (2) is significant at 5\% significance level. Meanwhile, the MA regression coefficient is 0.533 with the value of $t$ is significant at $1 \%$ significance level. In general, it can be concluded that the coefficient of autoregressive AR (1), AR (2), AR (3) and MA was such a clear explanation for the SRI-KEHATI Index. Makridakis et al. (1998) stated that the value of autoregressive coefficients can be positive or negative, as well as the moving average.
To conclude the hypothesis of this study, the Ljung-Box Q statistical test was conducted for the residual value of the ARIMA model $(3,1,1)$. The Ljung-Box Q value for residual statistics of this study with a lag of 18 is 25.970 , which is greater than the Chi-square table at a significance level of $5 \%$ with df 14 of 23.684 . Based on this, H1 stating that the past stock prices influence the future stock prices was accepted.

The ARIMA was in accordance with the data condition and relevant to be used in forecasting the stock prices on the Indonesia Stock Exchange. This happened because ARIMA combines the previous stock price (lag) as an autoregressive coefficient with a moving average, which is widely used by the investors in conducting the technical analysis. The significant autoregressive coefficient value indirectly supported the findings by Masih, Peters, and Mello (2010), which concluded that the previous stock price had a significant influence. The value of a significant moving average coefficient in this study provided an empirical evidence that moving average was such a real explanation in forecasting stock prices.

The findings of this study also showed that the objective of the technical analysis was that the right timing in forecasting short-term prices of stocks could be achieved by using the ARIMA method. This finding was also consistent with the findings of a research by Fernández-Rodríguez et al. (1999), Fernández-Rodríguez et al. (2000), which concluded that ARIMA was sufficient to be used as a tool to forecast the stock prices. This study also supported a statement saying that the technical analysis conducted on the ARIMA Index using the ARIMA method was adequate and relevant to be used on the Indonesia Stock Exchange.

\section{CONCLUSION}

This study found that the SRI-KEHATI Index data during the study period were a time series data that were not stationary. This caused the ARIMA analysis could not be directly conducted, because ARIMA required the data used to be stationary. In order to improve the data condition and to make them stationary, a transformation was done by using the first difference. The results of the data transformation showed that after being transformed, the data became stationary and could be used for ARIMA analysis.

The results of the transformation using the first differencing showed that the ARIMA model would use the $d$ value of 1 , while the determination of $p$ value was done using PACF, which showed that PACF on 
lag 1 was significant, so that lag 1 would be used as the autoregression coefficient. Considering the absence of the specific criteria in determining the value of the moving average $(q)$ coefficient, the $q$ value was determined as 1, according to the suggestion by Greene (2003) that effective $q$ values were the most minimum. Based on this, the ARIMA model used in this study was ARIMA $(1,1,1)$.

The ARIMA $(3,1,1)$ analysis results showed that the AR and MA coefficients had a significant effect on the SRI-KEHATI Index, showing that the regression coefficient in ARIMA was such a real explanation for the dependent variable. The Ljung-Box Q statistical test results showed that the ARIMA model was adequate and relevant to be used in conducting technical analysis on the SRI-KEHATI Index on the Indonesia Stock Exchange.

\section{SUGGESTION}

It is considered necessary for investors to conduct technical analysis in investing in the members of SRIKEHATI Index stocks on the Indonesia Stock Exchange. This technical analysis can be done by using the data of past stock price. Investors are also advised to use the ARIMA method to forecast the stock price of SRI-KEHATI members on the Indonesia Stock Exchange.

For the future researchers and academics who want to explore and conduct researches in the same field, it is recommended to conduct a study on other indicators of technical analysis given the many indicators of technical analysis available. Forecasting the stock price of SRI-KEHATI members with Generalized Autoregression Conditional Heteroscedasticity (GARCH) is also highly recommended. Furthermore, it is recommended to conduct a specific analysis on one stock, because each share has a price movement pattern that is different from each other.

\section{REFERENCES}

1. Ang, R. (1997). Buku Pintar Pasar Modal Indonesia. Jakarta: Mediasoft Indonesia.

2. Archelis, S. (2000). Technical Analysis From A to Z. Equis International.

3. Ardani, N., Murhadi, W. R., \& Marciano, D. (2012). Investasi: Komparasi Strategi Buy and Hold dengan Pendekatan Teknikal. Jurnal Akuntansi dan Keuangan, 14(1), 32-44.

4. Artha, D. R., Achsani, N. A., \& Sasongko, H. (2014). Analisis Fundamental, Teknikal Dan Makroekonomi Harga Saham Sektor Pertanian. Jurnal Manajemen dan Kewirausahaan, 16(2). https://doi. org/10.9744/jmk.16.2.175-184

5. Badev, A., \& Chen, M. (2014). Bitcoin: Technical Background and Data Analysis. Finance and Economics Discussion Series. Retrieved from https://www. federalreserve.gov/econresdata/ feds/2014/files/2014104pap.pdf
6. Ernayani, R., Oktiviana, S., \& Robiyanto, R. (2017). The Effect of Return on Investment, Cash Ratio, and Debt to Total Assets Towards Dividend Payout Ratio (A Study Towards Manufacturing Companies Listed in Indonesia Stock Exchange). Advanced Science Letters, 23(8), 7169-7199. https://doi. org/10.1166/asl.2017.9328

7. Fernández-Rodríguez, F., Gonzalez-Martel, C., \& Sosvilla-Rivero, S. (1999). Technical Analysis in the Madrid Stock Exchange (Working Paper). Retrieved from documentos.fedea.net/pubs/dt/1999/ dt-1999-05.pdf

8. Fernández-Rodríguez, F., SosvillaRivero, S., \& Andrada-Félix, J. (2000). Technical Analysis in Foreign Exchange Markets : Linear Versus Nonlinear Trading Rules (Working Papers on International Economics and Finance). Retrieved from https://ideas.repec. $\mathrm{org} / \mathrm{p} / \mathrm{fda} / \mathrm{fdadef} / 00-02 . \mathrm{html}$
9. Fildes, R., \& Makridakis, S. (1995). The Impact of Empirical Accuracy Studies On Time Series Analysis and Forecasting. International Statistical Review, 63, 289-308. https://doi.org/10.2307/1403481

10. Greene, W. H. (2003). Econometric Analysis (5th ed.). New Jersey: Prentice Hall.

11. Hartono, J. (2015). Teori portofolio dan analisis investasi (10th ed.). Yogyakarta, Indonesia: BPFE.

12. Khafid, M., \& Mukhibad, H. (2016). Apakah Kualitas Laba Berbasis Akuntansi Berkontribusi Terhadap Market Outcomes? Jurnal Keuangan dan Perbankan, 20(1), 42-49.

13. Makridakis, S. G., Wheelwright, S. C., \& Hyndman, R. J. (1998). Forecasting: Methods and Applications (3rd ed.). John Wiley \& Sons, Inc.

14. Martin, A. D. (2001). Technical Trading Rules in the Spot Foreign Exchange Markets of Developing 
Countries. Journal of Multinational Financial Management, 11, 59-68.

15. Masih, R., Peters, S., \& Mello, L. D. (2010). Oil Price Volatility and Stock Price Fluctuations in an Emerging Market: Evidence from South Korea (Working Paper).

16. Mukti, H. (2018). Penerapan Analisis Teknikal Ichimoku No Kinko Hyo Pada Saham JII (Jakarta Islamic Index). Skripsi, Universitas Islam Negeri Sunan Kalijaga, Yogyakarta, Indonesia.

17. Parisi, F., \& Vasquez, A. (2000). Simple Technical Trading Rules of Stock Returns: Evidence From 1987 to 1998 in Chile. Emerging Markets Review, 1, 152-164. https://doi.org/10.1016/S15660141(00)00006-6

18. Prabhata, A. (2012). Efektifitas Penggunaan Analisis Teknikal Stochastic Oscillator dan Moving Average Convergence-Divergence (MACD) Pada Perdagangan Saham-Saham Jakarta Islamic Index (JII) di Bursa Efek Indonesia. Sinergi Kajian Bisnis dan Manajemen, 13(1), 1-14.

19. Qizam, I. (2001). Analisis Kerandoman Perilaku Laba Perusahaan di Bursa Efek Jakarta. Paper presented at the Simposium Nasional Akuntansi IV IAI-KAPd.

20. Robiyanto, R. (2000). Pengaruh Hari Perdagangan Saham Terhadap Return Harian Saham di Bursa Efek Jakarta (Sebuah Studi Terhadap IHSG, Indeks Saham Sektoral dan Indeks Saham Unggulan (LQ 45). Jurnal Bisnis Strategi, 5, 46-94. https://doi. org/10.14710/jbs.5.3.48-58

21. Robiyanto, R. (2015). Month of the year effect pada beberapa pasar modal di Asia Tenggara dan pasar komoditas. Jurnal Ekonomi dan Bisnis, 18(2), 53-64. https:// doi.org/10.24914/jeb.v18i2.260

22. Robiyanto, R. (2017). Performance evaluation and risk aversion rate for several stock indices in Indonesia Stock Exchange. Jurnal Manajemen dan Kewirausahaan, 19(1), 60-64. https://doi. org/10.9744/jmk.19.1.60-64
23. Robiyanto, R. (2018). Performance Evaluation of Stock Price Indexes in the Indonesia Stock Exchange. International Research Journal of Business Studies, 10(3), 173-182. https://doi.org/10.21632/ irjbs.10.3.173-182

24. Robiyanto, R., \& Puryandani, S. (2015). The Javanese lunar calendar's effect on Indonesian stock returns. Gadjah Mada International Journal of Business, 17(2), 125-137. https://doi.org/10.22146/ gamaijb.6906

25. Robiyanto, R., Wahyudi, S., \& Pangestuti, I. R. D. (2017a). Testing Commodities as Safe Haven and Hedging Instrument on ASEAN's Five Stock Markets. Jurnal Ekonomi Kuantitatif Terapan, 10(2), 231-238. https://doi.org/10.24843/ JEKT.2017.v10.i02.p11

26. Robiyanto, R., Wahyudi, S., \& Pangestuti, I. R. D. (2017b). The volatility-variability hypotheses testing and hedging effectiveness of precious metals for the Indonesian and Malaysian capital markets. Gadjah Mada International Journal of Business, 19(2), 167-192. https://doi.org/10.22146/ gamaijb. 26260

27. Setiawan, S. T., \& Fathony, M. (2015). Analisis Fundamental, Teknikal dan Makroekonomi Pada Harga Saham Sektor Properti di Bursa Efek Indonesia (Working Paper).

28. Sharpe, W. F., Gordon, J. A., \& Bailey, J. V. (1995). Investment (5th ed.). New Jersey: Prentice Hall.

29. Sugiarto, \& Harijono (2000). Peramalan Bisnis. Jakarta: Gramedia Pustaka Utama.

30. Tobing, J. J. (2015). Pengaruh Faktor-Faktor Fundamental dan Teknikal Terhadap Harga Saham Perusahaan Pada Sektor Property Bursa Efek Indonesia Periode 2009-2013 (Working Paper).

31. Triyono, D., \& Robiyanto, R. (2017). The effect of foreign stock indexes and Indonesia's macroeconomics variables toward Jakarta Composite Stock Price Index (JCI). Advanced Science Letters, 23(8), 7211-7214. https://doi. org/10.1166/asl.2017.9332
32. Waworuntu, S. R., \& Suryanto, H. (2010). The Complementary Nature Of Fundamental And Technical Analysis Evidence From Indonesia. International Research Journal of Business Studies, 3(2). Retrieved from http://www.irjbs. com/index.php/jurnalirjbs/article/ viewFile/511/51

33. Wijaya, R. (2017). Kinerja Keuangan dan Ukuran Perusahaan terhadap Harga Saham dengan Kebijakan Dividen sebagai Variabel Intervening. Jurnal Keuangan dan Perbankan (JKP), 21(3).

34. Yudono, I. (2010). Analisis Teknikal Saham-Saham Sektor Pertambangan di Bursa Efek Indonesia. Performance, 11(2), 29-45.

35. Zulkafli, A. H., Ahmad, Z., \& M, E. E. (2017). The Performance of Socially Responsible Investments in Indonesia: A Study of the Sri Kehati Index (SKI). Gadjah Mada International Journal of Business, 19(1), 59-76. https://doi. org/10.22146/gamaijb.17959 